\title{
Bioremediation of Crude Oil Contaminated Soil Using Organic and Inorganic Fertilizers
}

\author{
Rowland U Ofoegbu*, Yusuf O L Momoh and Ify L Nwaogazie
}

Department of Environmental Engineering, University of Port Harcourt, P.M.B 5323, Choba, Port Harcourt, Rivers State. 500271, Nigeria

\begin{abstract}
The study involves the use of first-order kinetics model in the remediation of crude oil contaminated arable soil at 2, 4, and 6\% crude oil spill respectively, this was biostimulated with inorganic fertilizer (NPK), cow dung (CD), and palm kernel husk ash (PKHA) applied singly and in combinations (cow dung \& inorganic fertilizer); (cow dung \& palm kernel husk ash) in a 50:50 ratio. The experiment was a randomized complete block design (RCBD), which was conducted in two phases, i.e., the first block comprises of inorganic fertilizer and cow dung, while the second block consist of cow dung and palm kernel husk ash used singly and in combination. The degree of biodegradation was observed for a remediation period of 40 days under laboratory conditions. The results obtained reveal a positive correlation coefficient for the various biostimulants used. Also, student's t-test conducted reveals a significant $p<0.05$, in remediation for the various biostimulants, when compared with the unamended soil. This research study shows that a higher biodegradation rate constant $(\mathrm{k})$ and a low half life time $($,$) exist for amendments with (cow dung \&$ inorganic fertilizer) and gradually varies with other biostimulants. From the estimated biostimulation efficiency (B.E) and biodegradation rate constant $(\mathrm{k})$, the orders of remediation from the most treated are: A combination (inorganic fertilizer \& cow dung)> inorganic fertilizer used singly> cow dung used singly> combination (cow dung \& palm kernel husk ash)> and finally palm kernel husk ash used singly at 2, 4\% crude oil contamination, and inorganic fertilizer preceding before a combination (inorganic fertilizer \& cow dung) at $6 \%$ crude oil contamination.
\end{abstract}

Keywords: Biodegradation; Bio-stimulation; Fertilizer; Cow dung; Total hydrocarbon content

\section{Introduction}

Crude oil spillage has been a challenge, most especially in Nigeria. This is borne out of crude oil exploration and exploitation activities particularly in the oil rich Niger Delta States of Nigeria, which can be located between Longitude $3^{\circ} 19^{\prime}$ and $15^{\circ} 11^{\prime}$ East and Latitude $40^{\circ} 30^{\prime}$ and $14^{\circ} 34^{\prime}$ North. This region is very rich in hydrocarbon deposits, and these results in more than eighty percent of the Nation's Foreign Exchange earnings. The occupation of the inhabitants of the Niger Delta region where this crude oil are extracted are mostly subsistence farming and fishing, as the rivers, lakes and the adjoining Atlantic Ocean provides a good and favourable fishing activity. The oil spill penetrates to a depth of about $10-20 \mathrm{~cm}$ which has a major role to play in agricultural activities, resulting in the loss of soil fertility and also, initiates environmental degradation [1]. This singular process, renders the soil impotent, i.e., the soil cannot produce crops as well as it could before the spill. In this light, because of their concentration in the terrestrial environment, there is a complete breakdown of structures and dispersion of soil particles [2-4].

Crude oil spills arises from vandalism (sabotage, i.e., people robbing the pipeline of its products or to make claims for compensation as well as, cleaning contracts) of oil installations, corrosion of over aged oil facilities and via uncontrolled spillage in oil refineries, and storage tanks that pose inevitable consequence (i.e., damage) to our immediate environment. It is very important to realize that, the discharge of hydrocarbons into the environment by transportation via tankers and barges, does not limit crude oil spillage only to oil producing States, but also to neighbouring States that are prone to the risk of oil spill due to transportation accidents and ruptured pipelines network that runs across such areas. Oil spill pollution could also result from the sales, and uses of petroleum products, pipeline overflow, breakage, and storage tank spill $[5,6]$. This crude oil spills, alters the physicochemical properties of the soil [7], making it impossible for the soil to produce at its optimal capacity as a result of hardening of the soil structure by the oil [8-10]. The biostimulant involved in the study includes; palm kernel husk ash, cow dung and inorganic fertilizers, and have been shown that, the biostimulation efficiency of the crop residue and animal derived organic waste are marginally and relatively close [11].

Palm kernel husk is one major product that is generated from the processing of fresh palm fruits from which, palm oil is extracted. Apart from the highly mechanized oil palm processing plant, i.e., "Risonpalm company in Nigeria", other small scale oil palm processing mills are built and used by indigenous communities, most especially in Rivers, Imo, Akwa-Ibom, and Delta State, etc., to process there palm fruits. It had been observed by researchers that over twenty-two percent of the harvested palm fruits processed, ends up as palm kernel husk [12]. In larger modern mechanized oil palm processing mills, the waste thus generated are incinerated to generate heat energy to power boilers and are a means of getting rid of these waste $[12,13]$. By and large, the heap of ash resulting from the combustion of this waste, poses a major challenge to our small scale mills and also the environment. Currently in Nigeria, there is no large scale utilization of palm kernel husk ash (PKHA). Although, it can be utilized in local soap production because of its high potassium content and it is a very good source of potassium fertilizer [14]. Also, the combusted bunch ashes had been reported to aid the reduction of the bio-toxic level of oil polluted soil [15].

*Corresponding author: Rowland U Ofoegbu, Department of Environmental Engineering, University of Port Harcourt, P.M.B 5323, Choba, Port Harcourt, Rivers State 500271, Nigeria, Tel: 2348151734994; E-mail: rowlandofoegbu@gmail.com

Received September 18, 2014; Accepted October 29, 2014; Published November 07, 2014

Citation: Ofoegbu RU, Momoh YOL, Nwaogazie IL (2015) Bioremediation of Crude Oil Contaminated Soil Using Organic and Inorganic Fertilizers. J Pet Environ Biotechnol 5: 198. doi:10.4172/2157-7463.1000198

Copyright: (c) 2015 Ofoegbu RU, et al. This is an open-access article distributed under the terms of the Creative Commons Attribution License, which permits unrestricted use, distribution, and reproduction in any medium, provided the original author and source are credited. 
Nigeria is blessed with domestic birds and livestock's such as fowl, ram, sheep, cow, goat, and etc. These livestock's produces waste "dung's", and are abound in the cattle markets (i.e., slaughter houses), which are avenue for such dung's, and are considered waste. These wastes are considered useless to the ordinary man. But research has shown that such wastes are useful material to modify the soil physical and chemical properties and also, to release nutrients for a longer period of time. The biostimulants thus provided, maintains the favourable conditions for growth of the soil microorganisms [16-19]. This singular act is only possible via biodegradation which are facilitated by indigenous soil microbes. It is important to note that bioremediation is the controlled process of degradation of organic pollutants using soil microbes. It is the use of microorganisms to remove environmental pollutants of soil, water and sediments [20]. Biostimulation has been proven to be a promising bioremediation technique for the treatment of polluted soil aerobically [21,22]. Of recent, bioremediation technologies have gained wide acceptance in our modern day research because of the abilities of microbes to mineralize hydrocarbon components to its environmentally friendly products. Although, this bioremediation techniques can be limited by some environmental factors such as nutrients, $\mathrm{pH}$, temperature, moisture, oxygen, soil properties and contaminants concentration [23-27]. The key to an effective implementation of bioremediation process involves: to maintain an optimal nutrient, and control some prevalent environmental parameters in an order that will promote the survival and growth of soil microbes. In this study, the rate of bioremediation was studied by the use of various stimulants capable of providing nutrients to enhance microbes found in the soil, and comparing such results obtained with control (unamened) in order to understand the dynamics of crude oil degradation in the Niger Delta soil of Nigeria.

Therefore, the research work explores the effectiveness of organic manure (i.e., cow dung, palm kernel husk ash) and inorganic fertilizer (NPK) towards enhancing microbial biodegradation of hydrocarbon polluted arable soil. Also, the work aims at assessing whether selfcleansing is operational and what type of biostimulants would lead to an enhanced biodegradation of the affected soil. These were ascertained, using the first order kinetics model and the students statistical test method.

\section{Materials and Method}

\section{Description of study region}

The soil sample used in this study was collected from Rumuolumeni town in Obio/ Akpor Local Government Area of Rivers State, Nigeria. The main occupations of the people are land farming and subsistent agriculture, of which there is no history of crude oil pollution in this environment. The palm kernel husk was obtained from a palm oil mill plant at Ubima in Rivers State, while cow dung was obtained from slaughter house in Trans-Amadi, Rivers State.

\section{Sample collection}

The following materials were utilized in the course of this study, they includes:

\section{Cow Dung (CD);}

\section{AI. Palm Kernel Husk Ash (PKHA);}

\section{BI. Inorganic Fertilizer (NPK)}

The cow dung was sun dried for three week after which it was ground into powdered form. The ground cow dung was passed through a $2 \mathrm{~mm}$ standard mesh sieve thereafter, some samples of the powdered cow dung were sent to the laboratory for the determination of its minerals content such as carbon, nitrogen and phosphorus, etc. This was carried out to ascertain the remediating properties of the organic manure used (cow dung). The husk was shredded into smaller pieces after which it was sun dried for three weeks. At the expiration of the third week, the shredded and dried husk was combusted and afterword, ground into powdered form. The ground palm kernel husk ash was passed through a $2 \mathrm{~mm}$ standard mesh sieve and thereafter, some sample were taken for analysis of some mineral constituents, e.g., carbon, nitrogen, phosphorus and nitrate, etc., as presented in Table 1. The inorganic fertilizer (NPK; 15-15-15) which is composed of nitrogen, phosphorus and potassium was bought from an agro-chemical shop.

\section{Physicochemical determination of samples}

The organic manure that were used for this study, together with the soil sample were analysed using standard methods; the $\mathrm{pH}$ was determined by the according to the modified method of McLean [28], the total organic carbon was determined by the modified [29] wet combustion method [30], available nitrogen was ascertained using semi-micro Kjeldhal method [31], the available phosphorus by Brays No.1 method [32], while the exchangeable cations, sodium and potassium, magnesium values were determined by flame photometry.

\section{Determination of total hydrocarbon content (THC)}

The total hydrocarbon content was analysed using standard solvent extraction method [33]. A gram of the sieved soil sample was dissolved in chloroform in a test tube. Thereafter, the clear lower layer was collected with a clean test tube upon which, it was dehydrated by the addition of a spoonful of anhydrous sodium sulphate. The clear extracted solution was absorbed at $420 \mathrm{~nm}$ HACH DR/2010 spectrophotometer. The total hydrocarbon content concentration was extrapolated with a reference from a standard curve obtained from the graph of produced crude oil at varying concentrations.

\section{Ex-Situ bioremediation procedure}

The soil samples were dug to a depth of $0-15 \mathrm{~cm}$. The excavated top soil, unlike the cow dung and palm kernel husk ash was sun dried for duration of three weeks and were ground using a mortar and a pestle. Thereafter, they were sieved using a $2 \mathrm{~mm}$ standard mesh sieve and were measured with an electronic weighing balance. This remediation exercise was carried out in a well perforated 1.5 litres plastic container with an estimated depth of $13 \mathrm{~cm}$. Bioremediation is ineffective at a depth below $150 \mathrm{~mm}$ [34]. The Randomized Complete Block Design used, were divided into two block design with each block accommodating a maximum of twelve (12) cells each consist of the following:

i. The crude oil contamination was in the proportions of 2, 4 and $6 \%$ respectively;

\begin{tabular}{|c|c|c|c|}
\hline PARAMETERS & SOIL & CD & PKHA \\
\hline pH & 6.37 & 8.30 & 6.12 \\
\hline Organic carbon (\%) $\mathbf{1} \mathbf{1 0}^{-1}$ & 27.80 & 138.00 & 5.80 \\
\hline Nitrogen (\%) & 0.07 & 34.30 & 17.80 \\
\hline Phosphate (mg/kg) & 1.90 & 19.62 & 118.20 \\
\hline Potassium (mg/kg) & 9.64 & 8.53 & 18.34 \\
\hline Magnesium $\mathbf{( m g / k g )}$ & 21.50 & 3.56 & 10.20 \\
\hline Sodium $\mathbf{( m g / k g )}$ & 12.08 & 2.30 & 4.63 \\
\hline
\end{tabular}

Table 1: Preliminary Analysis for soil, cow dung (CD) and palm kernel husk ash (PKHA). 
ii. The nutrients in the first block design consist of $2 \mathrm{~g}$ NPK, $40 \mathrm{~g}$ $\mathrm{CD}$ and (1g NPK $+20 \mathrm{~g} \mathrm{CD})$ per $1000 \mathrm{~g}$ soil, while the second block design consist of $40 \mathrm{~g} \mathrm{CD}, 40 \mathrm{~g}$ PKHA, $(20 \mathrm{~g} \mathrm{CD}+20$ g PKHA) per $1000 \mathrm{~g}$ soil respectively, with each block design having a maximum of three (3) Controls; and

iii. The individual cells were moisten and mixed by the aid of a stirrer. This stirring exercise was conducted every four days for an effective aeration.

This research work was conducted for six weeks, during which samples from the twenty-four labelled cells were taken to the laboratory for analysis of total hydrocarbon content, once in every eight days. Total hydrocarbon content was analysed using standard methods [33].

\section{Mathematical models}

Biodegradation kinetics: Biodegradation is the controlled degrading of soil contaminants by microorganism. The extent of remediation offered by these microbes is best articulated from the biodegradation kinetic model as explained by the first order kinetic [35-37]. The biodegradation rate was compared using the reaction rate constant for the first order kinetic equation is as presented in Eq. (1):

$$
\operatorname{In} C_{t}=\operatorname{In} C_{0}-k t
$$

Biodegradation half-life time and percentage degradation (\%D): The biodegradation kinetics gives the performance of microbes in the soil [38]. The biodegradation half-life $t_{1 /}$ that was presented in Eq. (2); is the time required for contaminant corrcentration to reduce to half of their original concentration.

$$
t_{1 / 2}=\frac{0.6932}{k}=\frac{\ln 2}{k}
$$

where $t_{1 / 2}$ is the half life time, $\mathrm{k}$ is the biodegradation rate constant. This model ${ }^{2}$ gives us a working knowledge of the concentration of contaminants present at a given time; it also enables us to make future predictions. The degree of degradation (D) was calculated using Eq. (3):

$$
\% D=\frac{T H C_{0}-T H C_{i}}{T H C_{0}} \times 100
$$

Where and are the initial and residual total hydrocarbon content concentrations respectively.

Bio-stimulation efficiency (B.E): The effectiveness of any remediation program is necessitated by some factors. These factors could be biotic (involving life) or abiotic (not involving life). Be that as it may, no remediation exercise can attain complete remediation, but rather the mitigation level could be high to encourage thrive of life. This is so, as no single bacterium is capable of complete biodegradation $[39,40]$. The efficiency of stimulation gives insight to the treatability

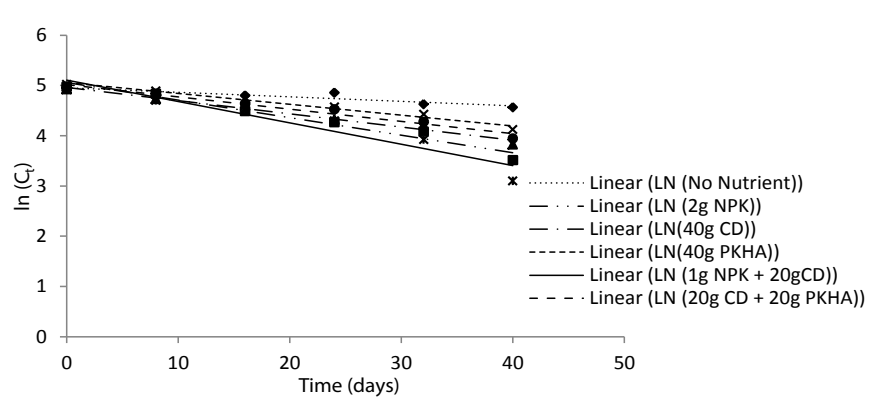

Figure 1: Kinetic pattern for THC reduction at $2 \%$ crude oil spill contamination using various biostimulants. options offered by the various biostimulants approach [11]. This is seen in Eq. (4):

$$
B . E=\frac{\% T H C_{(T)}-\% T H C_{(U)}}{\% T H C_{(T)}} \times 100 \%
$$

Where represents the percentage removal of crude oil in the biostimulated soil and, is the percentage removal of crude oil in the nonbio-stimulated soil.

\section{Results and Discussion}

\section{Total hydrocarbon content evaluation}

The degree of biodegradation of crude oil spill at 2, 4 and $6 \%$ concentrations were analysed for the various bio-stimulated cells and from the data gathered. The removal effect of total hydrocarbon content which was used as an indicator parameter for remediation at various levels of crude oil contamination, i.e., 2, 4, 6\%, and these were observed to reduce with time for the various applied nutrients (bio-stimulants). This signifies that there was an improvement in the efficiency or degree of remediation offered by the various bio-stimulants.

\section{Application of first order reaction for kinetic study}

The biodegradation rates were compared using biodegradation rate constants, from the First Order Kinetics Model, which was performed using the linear function of Microsoft Excel Statistical tool pack. The graphs of the kinetic pattern for total hydrocarbon content reduction at 2,4 and $6 \%$ contamination levels for various bio-stimulated cells when cultured for a remediation period of 40days, using the linest function of Micro Soft Excel pack tool, are shown in Figures 1-3.

It was observed that the first order kinetic model (Eq. 1) fitted well to the biodegradation offered by the various biostimulants. This was illustrated in Figure 1. The biodegradation rate reveals a positive correlation coefficient $\mathrm{R}^{2}$ for the reduction in total hydrocarbon content, with a higher biodegradation rate at a reduced time. This implies that at $2 \%$ crude oil treatment, biodegradation rate constant $(\mathrm{k})$ and half-life $\left(t_{1 / 2}\right)$ are as shown in Table 2, it can be observed also, that the polluted soil amended with a combination (NPK \& CD), reveals a higher $\mathrm{k}$ $\left(0.042\right.$ day $\left.^{-1}\right)$, and at a lower $t_{1 / 2}(16.5$ days $)$; and was closely followed by the soil amended with NPK applied singly $\left(\mathrm{k}=0.035 \mathrm{day}^{-1}, \mathrm{t}_{1 / 2}=19.8\right.$ days); and also followed by the soil amended with $\mathrm{CD}$ applied singly ( $\mathrm{k}=0.026$ day $^{-1}, \mathrm{t}_{1 / 2}=26.7$ days); this was followed with soil amended with a combination of (PKHA \& CD) $\left(\mathrm{k}=0.024 \mathrm{day}^{-1}, \mathrm{t}_{1 / 2}=28.9\right)$, PKHA $\left(\mathrm{k}=0.021\right.$ day $^{-1}, \mathrm{t}_{1 / 2}=33$ days $)$, and control has the lowest value of $\mathrm{k}(0.009$ day $^{-1}$ ) and the highest $t_{1 / 2}$ (77 days). Also, results of biostimulation efficiency by the various biostimulants reveals that the combination of (NPK \& CD), NPK, CD, (PKHA \& CD), PKHA were able to remediate the soil by; $62.1,58.2,51.9,50.2$ and $46.0 \%$ respectively.

Furthermore, the bioremediation kinetics pattern (Figure 2), also reveals a positive correlation coefficient $\mathrm{R}^{2}$ for the reduction in total hydrocarbon content concentration at $4 \%$ crude oil treatment. This also, is shown in Table 2. From the result, the biodegradation rate constant (k) was high for a combination of (NPK \& CD), i.e., $k\left(0.031\right.$ day $\left.^{-1}\right)$ with the lowest half-life, i.e., $\mathrm{t}_{1 / 2}$ (22.4 days), this was closely followed with the amended soil with NPK applied alone $\left(\mathrm{k}=0.022 \mathrm{day}^{-1}, \mathrm{t}_{1 / 2}=31.5\right.$ vdays $)$, and also followed by the soil amended with $\mathrm{CD}$ alone $\left(\mathrm{k}=0.022 \mathrm{day}^{1}\right.$, $\mathrm{t}_{1 / 2}=31.5$ days), a combination of PKHA \& CD ( $\mathrm{k}=0.021$ day $^{-1}, \mathrm{t}_{1 / 2}=33$ days), PKHA ( $\mathrm{k}=0.018$ day $^{-1}, \mathrm{t}_{1 / 2}=38.5$ days), and the control, having the lowest biodegradation rate constant $\mathrm{k}\left(0.007 \mathrm{day}^{-1}\right)$, and highest $\mathrm{t}_{1 / 2}(99$ days). The result of bio-stimulation efficiency as by these bio-stimulants reveals that the combination of (NPK and CD), NPK, CD, (PKHA and CD), PKHA were able to remediate the soil by $58.1,52.7,49.8,48.7$ 
Citation: Ofoegbu RU, Momoh YOL, Nwaogazie IL (2014) Bioremediation of Crude Oil Contaminated Soil Using Organic and Inorganic Fertilizers. J Pet Environ Biotechnol 6: 198. doi:10.4172/2157-7463.1000198

Page 4 of 6

\begin{tabular}{|c|c|c|c|c|c|c|c|}
\hline Rate & Bio-stimulants & Weight & Kinetics Equation & $\mathrm{K}\left(\right.$ day $\left.^{-1}\right)$ & $t 1 / 2$ (days) & $\%$ D & B.E \\
\hline \multirow{6}{*}{$2 \%$} & NPK + CD & $1 g+20 g$ & $Y=-0.042 X+5.108$ & 0.042 & 16.5 & 84.62 & 62.1 \\
\hline & NPK & $2 \mathrm{~g}$ & $Y=-0.035 X+5.058$ & 0.035 & 19.8 & 76.80 & 58.2 \\
\hline & CD & $40 \mathrm{~g}$ & $Y=-0.026 X+4.962$ & 0.026 & 26.7 & 66.80 & 51.9 \\
\hline & PKHA + CD & $20 \mathrm{~g}+20 \mathrm{~g}$ & $Y=-0.024 X+5.016$ & 0.024 & 28.9 & 64.44 & 50.2 \\
\hline & PKHA & $40 \mathrm{~g}$ & $Y=-0.021 X+5.058$ & 0.021 & 33.0 & 59.45 & 46.0 \\
\hline & CONTROL & - & $Y=-0.009 X+4.953$ & 0.009 & 77.0 & 32.11 & - \\
\hline \multirow{6}{*}{$4 \%$} & NPK + CD & $1 g+20 g$ & $Y=-0.031 X+5.479$ & 0.031 & 22.4 & 71.80 & 58.1 \\
\hline & NPK & $2 \mathrm{~g}$ & $Y=-0.022 X+5.492$ & 0.022 & 31.5 & 63.54 & 52.7 \\
\hline & CD & $40 \mathrm{~g}$ & $Y=-0.022 X+5.402$ & 0.022 & 31.5 & 59.97 & 49.8 \\
\hline & PKHA + CD & $20 g+20 g$ & $Y=-0.021 X+5.492$ & 0.021 & 33.0 & 58.60 & 48.7 \\
\hline & PKHA & $40 \mathrm{~g}$ & $Y=-0.018 X+5.470$ & 0.018 & 38.5 & 52.47 & 42.7 \\
\hline & CONTROL & - & $Y=-0.007 X+5.495$ & 0.007 & 99.0 & 30.08 & - \\
\hline \multirow{6}{*}{$6 \%$} & $\mathrm{NPK}+\mathrm{CD}$ & $1 g+20 g$ & $Y=-0.021 X+5.875$ & 0.021 & 33.0 & 58.60 & 51.7 \\
\hline & NPK & $2 \mathrm{~g}$ & $Y=-0.022 X+5.848$ & 0.022 & 31.5 & 58.83 & 51.9 \\
\hline & CD & $40 \mathrm{~g}$ & $Y=-0.018 X+5.801$ & 0.018 & 38.5 & 50.90 & 44.4 \\
\hline & PKHA + CD & $20 g+20 g$ & $Y=-0.015 X+5.770$ & 0.015 & 46.2 & 45.31 & 37.5 \\
\hline & PKHA & $40 \mathrm{~g}$ & $Y=-0.013 X+5.835$ & 0.013 & 53.3 & 41.50 & 31.8 \\
\hline & CONTROL & - & $Y=-0.007 X+5.840$ & 0.007 & 99.0 & 28.30 & - \\
\hline
\end{tabular}

$\% D=$ Percentage degradation, B.E = Bio-stimulation efficiency

Table 2: Results of Decay Equation, Biodegradation Rate Constant (K) And Half-life (, ) time of the various biostimulants.

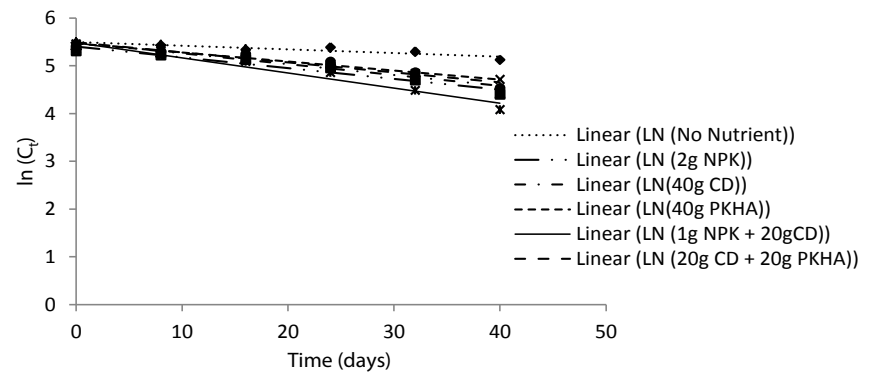

Figure 2: Kinetic pattern for THC reduction at $4 \%$ crude oil spill contamination using various biostimulants.

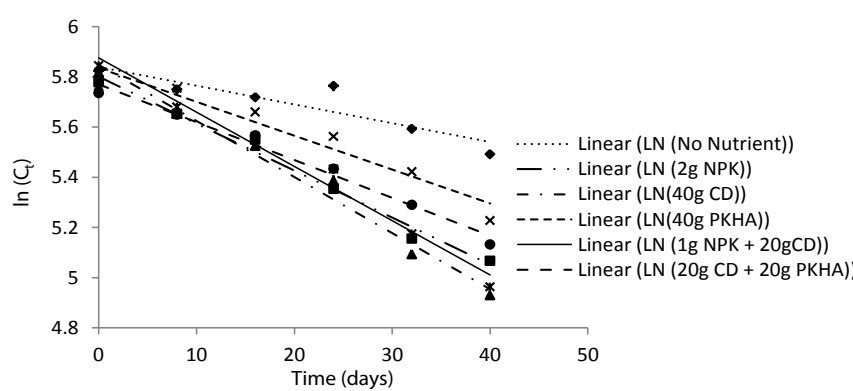

Figure 3: Kinetic pattern for THC reduction at $6 \%$ crude oil spill contamination using various biostimulants.

and $42.7 \%$ respectively. This reveals a slight decrease in the degree of biodegradation which could be attributed by the increase i.e., almost double in the crude oil spill concentration of the polluted soil.

Finally, the first order kinetic pattern for the total hydrocarbon content reduction (Figure 3), revealed that at $6 \%$ crude oil treatment; there was an increase in the biodegradation rate constant $(\mathrm{k})$, which represents half of the biodegradation rate constant and reduction in the half-life $\left(\mathrm{t}_{1 / 2}\right)$, which represents almost double of the half-life time at $2 \%$ crude oil contamination. This result reveal that at $6 \%$ crude oil contamination, the order of remediation would be: for a combination of (NPK and CD) indicates $\left(\mathrm{k}=0.021 \mathrm{day}^{-1}, \mathrm{t}_{1 / 2}=33\right.$ days); and is closely followed with NPK ( $\mathrm{k}=0.022$ day $^{-1}, \mathrm{t}_{1 / 2}=31.5$ days); CD ( $\mathrm{k}=0.018$ day ${ }^{1}, \mathrm{t}_{1 / 2}=38.5$ days $) ;$ PKHA + CD ( $\mathrm{k}=0.015$ day $^{-1}, \mathrm{t}_{1 / 2}=46.2$ days $) ;$ PKHA $\left(\mathrm{k}=0.013 \mathrm{day}^{-1}, \mathrm{t}_{1 / 2}=53.3\right.$ days $)$; and the control having the lowest biodegradation rate constant $\mathrm{k}\left(0.007 \mathrm{day}^{-1}\right)$ and $\mathrm{t}_{1 / 2}(99$ days $)$. The result of biostimulation by these biostimulants reveals that NPK, and the combination of (NPK and CD), CD, (PKHA and CD), PKHA were able to remediate the soil by $51.9,51.7,44.4,37.5$ and $31.8 \%$ respectively. This further shows decrease in the degree of biodegradation which could be attributed by the increase i.e., almost triple in the crude oil spill concentration in the polluted soil.

It could be deduced (Table 2), which represents the summary results obtained from the bioderadation process, with the order of treatment for 2 and $4 \%$ crude oil contamination in descending order of remediation as: $(\mathrm{NPK}+\mathrm{CD})>\mathrm{NPK}>\mathrm{CD}>(\mathrm{CD}+\mathrm{PKHA})>$ PKHA. While a similar trend was also observed with NPK being the most efficient biostimulant (Table 2), reveals that the order of treatment for $6 \%$ crude oil contamination in descending order of remediation: NPK $>(\mathrm{NPK}+\mathrm{CD})>\mathrm{CD}>(\mathrm{CD}+\mathrm{PKHA})>$ PKHA. A similar trend was observed in the research study conducted by $[6,10]$. The variation in the treatment as was observed by the biostimulants, shows that the degree of biodegradation decreases with an increase in the levels of crude oil contamination.

Further analysis on the remediation offered by the various biostimulants, were also ascertained by the student's t-test using Microsoft Excel analysis tool pack, with the following considerations: A Null hypothesis $\left(\mathrm{H}_{0}\right)$ of $\mathrm{p}>0.05$, which indicates no significant effect on remediation process, while an Alternative hypothesis $\left(\mathrm{H}_{1}\right)$ of $\mathrm{p}<0.05$; which indicate a significant effect on remediation process. From the student's t-test results shown in Table 3, a significant level $(\mathrm{P}<$ $0.05)$ was observed for treatment with NPK, CD, PKHA, $(\mathrm{NPK}+\mathrm{CD})$ and (CD+PKHA) as nutrients at 2, 4 and $6 \%$ crude oil contamination when compared with Control. Firstly, at $2 \%$ crude oil spill significant levels were observed for the various biostimulants; NPK (3.593E02), CD (1.5612E-02), PKHA (1.586E-02), combination of NPK and $\mathrm{CD}(2.4074 \mathrm{E}-02)$ and combination of $\mathrm{CD}$ and PKHA (3.599E-02) 
Citation: Ofoegbu RU, Momoh YOL, Nwaogazie IL (2014) Bioremediation of Crude Oil Contaminated Soil Using Organic and Inorganic Fertilizers. J Pet Environ Biotechnol 6: 198. doi:10.4172/2157-7463.1000198

Page 5 of 6

\begin{tabular}{|c|c|c|c|c|}
\hline Rate & BIOSTIMULANTS & Weight & P-value & Remarks \\
\hline \multirow{5}{*}{$2 \%$} & NPK & $2 \mathrm{~g}$ & 0.0359 & Significant difference \\
\hline & CD & $40 \mathrm{~g}$ & 0.0156 & Significant difference \\
\hline & PKHA & $40 \mathrm{~g}$ & 0.0159 & Significant difference \\
\hline & NPK + CD & $1 \mathrm{~g}+20 \mathrm{~g}$ & 0.0241 & Significant difference \\
\hline & PKHA + CD & $20 \mathrm{~g}+20 \mathrm{~g}$ & 0.0360 & Significant difference \\
\hline \multirow{5}{*}{$4 \%$} & NPK & $2 \mathrm{~g}$ & 0.0074 & Significant difference \\
\hline & CD & $40 \mathrm{~g}$ & 0.0017 & Significant difference \\
\hline & PKHA & $40 \mathrm{~g}$ & 0.0054 & Significant difference \\
\hline & NPK + CD & $1 \mathrm{~g}+20 \mathrm{~g}$ & 0.0050 & Significant difference \\
\hline & PKHA + CD & $20 \mathrm{~g}+20 \mathrm{~g}$ & 0.0095 & Significant difference \\
\hline \multirow{5}{*}{$6 \%$} & NPK & $2 \mathrm{~g}$ & 0.0148 & Significant difference \\
\hline & CD & $40 \mathrm{~g}$ & 0.0094 & Significant difference \\
\hline & PKHA & $40 \mathrm{~g}$ & 0.0219 & Significant difference \\
\hline & $\mathrm{NPK}+\mathrm{CD}$ & $1 g+20 g$ & 0.0252 & Significant difference \\
\hline & PKHA + CD & $20 \mathrm{~g}+20 \mathrm{~g}$ & 0.0030 & Significant difference \\
\hline
\end{tabular}

Table 3: Summary of the students' t-test conducted for the various biostimulants.

respectively, meaning that there is a significant difference. Secondly, at $4 \%$ crude oil contamination, the significant levels for biostimulants; NPK (7.38E-03), CD (1.663E-03), PKHA (1.0827E-03), combination of NPK and CD (4.99E-03) and combination of CD and PKHA (9.531E$03)$ respectively. Finally, at $6 \%$ crude oil contamination, the significant levels are; NPK (1.4783E-02), CD (9.364E-03), PKHA (2.1898E-02), combination of NPK and CD (2.5154E-02), combination of CD and PKHA (2.976E-03) respectively. So we accept the Alternative Hypothesis $\left(\mathrm{H}_{1}\right)$, which indicates a significant reduction in crude oil contamination for the various biostimulants with respect to time. The applied fertilizer increases the biodegradation rate when compared with the control [41]. Also, similar trend has been observed by [14].

\section{Conclusion}

The technology for bioremediation that was employed in this study was a simple, effective, inexpensive and environmentally friendly approach, whose biostimulant availability is compatible to the environment and is mainly of organic origin, i.e., residue of animal (cow dung) and plant residue (palm kernel husk ash), which are often regarded as waste and are of no economic value to the ordinary man. Remediation for the oil contaminated soil at the end of six weeks revealed a positive correlation coefficient in the degree of remediation by the various biostimulants, during the trial periods. Also, it shows that:

Firstly, the percentage degradation of total hydrocarbon content as revealed from Table 2 for soils contamination at $2 \%$ crude oil spill, as were biostimulated, shows the highest order of remediation 84.62 and $76.80 \%$, were observed for biostimulant of combination (cow dung $\&$ inorganic fertilizer) and inorganic fertilizer, while 66.8 and $64.44 \%$ remediation levels for cow dung and a combination (cow dung \& palm kernel husk ash), and was lastly accompanied by palm kernel husk ash (59.45\%).

Secondly, at $4 \%$ crude oil spill contamination the percentage degradation of total hydrocarbon content reveals that biostimulants amended with a combination (inorganic fertilizer and cow dung) and cow dung recorded the highest values of 71.80 and $63.54 \%$, and this was followed closely with treatment by cow dung and a combination of (cow dung and palm kernel husk ash) at 59.97 and 58.60\% degradation level, and lastly accompanied by palm kernel hush ash (52.47\%).

Finally, also from Table 2 it can be observed that at $6 \%$ treatment of crude oil contamination, that were biostimulated, revealed the highest degree of biodegradation of 58.83 and $58.60 \%$ as were observed for inorganic fertilizer and a combination (inorganic fertilizer and cow dung), this was closely accompanied with a treatment of 50.90 and $45.31 \%$ as were obtained for cow dung and combination (cow dung and palm kernel husk ash). Lastly, biostimulants treated with palm kernel hush ash recorded the least $(41.50 \%)$. The above result indicates that the percentage degradation of total hydrocarbon content reduces as the volume of the crude oil spill increases and there was a significant difference in the biostimulation efficiency of the biostimulated soils (i.e., used singly and a combination of biostimulants).

From the forgoing, it is important to note that the biostimulation efficiency for the various biostimulants used, shows a significant level of remediation with decreasing order of treatment: $(\mathrm{CD} \& \mathrm{NPK})>\mathrm{NPK}>\mathrm{CD}>(\mathrm{CD} \& \mathrm{PKHA})>\mathrm{PKHA}$. This process involving the use of organic manure has been considered for their potential in biodegradation and biotransformation of petroleum products, which indicates that biostimulation methods are more efficient and cheaper than chemical processes. Thus, biodegradation technique employed for this degradation of crude oil soil matrix by promoting soil microbe's ability to biotransform petroleum hydrocarbons into less toxic compounds. Although, this laboratory scale research study can also be applied on a large scale study because the manure thus used are environmentally friendly and have been observed to promote the biodegradation of hydrocarbons.

\section{References}

1. Ogaji SOT, Ayotamuno MJ, Kogbara RB, Probert SD (2005) Bioremediation of a crude oil polluted agricultural soil at Port-Harcourt, Nigeria. School Engineering Cranfield University, Bedfordshire, UK.

2. Banat IM, Makkar RS, Cameotra SS (2000) Potential commercial applications of microbial surfactants. Appl Microbiol Biotechnol 53: 495-508.

3. Ezra S, Feinstein S, Pelly I, Bauman D, Miloslavsky I (2000) Weathering of fuel oil spill on the east Mediterranean coast. Ashdod, Israel Organic Geochemistry 31: $1733-1741$.

4. Rowell MJ (1977) Effect of crude oil spills on soils: A review of literature in the reclamation of agricultural soils after oil spills Part 1 . Toogood JA (editor) AP No M-17-11 University of Alberta, Canada.

5. Henry G, Heinke GW (1996) Environmental Science and Engineering (2ndedn). Englewood, NJ: Pretence-Hall.

6. Obire O, Wemedo SA (1996) Effect of oilfield wastewater on the microbial population of a soil in Nigeria. Niger Delta Biologia 1: 77-85.

7. Gesinde AF, Agbo EB, Agho MO, Dike EFC (2008) Adsorption of pesticides on 
Citation: Ofoegbu RU, Momoh YOL, Nwaogazie IL (2014) Bioremediation of Crude Oil Contaminated Soil Using Organic and Inorganic Fertilizers. J Pet Environ Biotechnol 6: 198. doi:10.4172/2157-7463.1000198

the meshed corncobs. Int J Pure Appl Sci 2: 37-44.

8. Ana OE (2000) Remediation potential of petroleum refinery waste contaminated land at Alsesa Eleme, Rivers State. M Eng Thesis: University of Port Harcourt.

9. Ezeonu CS (2010) Impact of soluble metal salts and crude oil contaminants on water retention capacity of soil and protein content of Zea mays. EJEAFChe 9: 885-891.

10. Wilford PG (2004) Contaminated Soil Treatment: The Evolution of Thermal Desorption Technology.

11. Agarry SE, Aremu MO, Aworanti OA (2013) Kinetic modelling and half- life study on enhanced soil bioremediation of bonny light crude oil amended with crop and animal-derived organic waste. J Pet Environ Biotechnol 4: 137.

12. Lim KH, Zaharah AR (2000) Decomposition and $\mathrm{N}$ and $\mathrm{K}$ release by oil palm empty fruit bunches applied under mature palms. Journal of Oil Palm Research 12: $55-62$.

13. Opoku J, Asante FA (2008) Palm oil production in Ghana; Final reports on the status of the oil palm industry in Ghana, German Technical Co-operation (GTZ). Accra, Ghana.

14. Adenipekun CO, Lawal Y (2011) Mycoremediation of Crude Oil and Palm Kernel Contaminated Soils by PleurotuspulmonariusFries (Quelet). Nature and Science 9: 125-131.

15. Onweremadu EU, Chukwucha NB, Idoko MA (2007) Distribution and remediation of two contaminant metal in soils proximal to Three Nigerian Roads. New York Science Journal, Science Pub Org.

16. Allard AS, Neilson AH (1997) Bioremediation of organic waste sites: a critical review of microbiological aspects. International Biodeterioration and Biodegradation 39: 253-285.

17. Mikszewski A (2004) Emerging technologies for the in situ remediation of PCB-contaminated soils and sediments: Bioremediation and nanoscale zerovalent Iron, Status Report prepared for the U.S. EPA Technology Office under a Technology Innovation Program Washington, DC, USA.

18. Norris RD, Hinchee RE, Brown R, McCarty PL, Semprini L et al (1994) Handbook of bioremediation. Boca Raton: Lewis.

19. USEPA (2006) In-situ and ex-situ biodegradation technologies for remediation of contaminated sites, EPA/625/R-06/015.

20. Pala M, De Carvalho D, Pinto D, Sant Anna Jr G L (2006) A suitable mode to describe bioremediation of a petroleum-contaminated soil. J Int Biodeter \& Biodegr 58: 254-260.

21. Rosenberg E, Lagmann R, Kushmaro A, Taube R, Adler R, et al. (1992) Petroleum bioremediation-A multiphase problem. Biodegradation 3: 337-350.

22. Venosa AD, Lee K, Suidan MT, Garcia-Blanco S, Cobanli S, et al. (2002) Bioremediation and biorestoration of a crude oil contaminated freshwater wetland on the St. Lawrence River. Bioremediation journal 6: 261-281.

23. Atlas RM, Bartha R (2006) Fate and effects of polluting petroleum in the marine environment. Residue Rev 49: 49-83.

24. Ghazali FM, Rahman RNZA, Salleh AB, Basri M (2004) Biodegradation of hydrocarbons in soil by microbial consortium. J Int Biodeter \& Biodegr 54: 61-67.
25. Sabate J, Vinas M, Solanas AM (2004) Laboratory-scale bioremediation experiments on hydrocarbon-contamined soil. J Int Biodeter \& Biodegr Journal 54: 19-25.

26. Semple KT, Reid BJ, Fermor TR (2001) Impact of composting strategies on the treatment of soils contaminated with organic pollutants. Environmental Pollution 112: 269-283

27. Walter M, Boyd-Wilson KSH, McNaughton D, Northcott G (2005) Laboratory trials on the bioremediation of aged pentachlorophenol residues. J Int Biodeter \& Biodegr 55: 121-130.

28. McLean EO (1982) Soil pH and lime requirement. Black C A (ed.): Methods in soil analysis: chemical and microbiological properties. Part II-American Society of Agronomy, Madison, Wisconsin, USA

29. Nelson DW, Sommers LE (1982) Determination of organic carbon. In: Page A L Miller R H, Keeney D R (eds): Methods of soil analysis, vol 2. Am. Soc. Agron. Madison, p. 539

30. Walkey A, Black Al (1934) An examination of the Degtjareff methods for determining soil organic matter and proposed modification of the chromic acid titration method. Soil Science 37: 29-38.

31. Bremner JM, Mulvaney CS (1982) Total nitrogen determination. In: Page AL, Miller RH, Keeney DR (eds): Method of soil analysis, Am Soc Agron.

32. Olsen SR, Sommers LE (1982) Determination of available phosphorus. In Page AL, Miller RH, Keeney DR (eds): Methods of soil analysis, Am Soc Agron Madison.

33. APHA, AWWA, WPCF (1992) Standard Methods for the Examination of Water and Wastewater, 18th ed. American Public Health Association, Washington DC, USA.

34. Deuel L, Holliday GH (1997) Soil Remediation for Petroleum Extraction Industry, soil Analytical services, College Station, TX, USA.

35. Dimitrov S, Pavlov T, Nedelcheva D, Reuschenbach P, Silvani M (2007) A kinetic model for predicting biodegradation. SAR QSAR Environ Res 18: 443457.

36. Maletic S, Dalmacija B, Roncevic S, Agbaba J, Petrovic O (2009) Degradation Kinetics of an Aged Hydrocarbon Contaminated soil. Water, Air and Soil Pollution 202: 149-159.

37. Matthies M, Witt J, Klasmeier J (2008) Determination of soil biodegradation half-life from simulation testing under aerobic laboratory conditions: a kinetic model approach. Environ Pollut 156: 99-105

38. Elektorowicz M (1994) Bioremediation of Petroleum contaminated clayey soi with pre-treatment. Environ Technol 15: 373-380.

39. Odu CTI (1972) Microbiology of soils contaminated with petroleum hydrocarbon, Extent of contamination and some soil and microbial properties after contamination. J Institute of Petroleum 58: 201-204.

40. Zhou E, Crawford RL (1995) Effects of oxygen, nitrogen and temperature on gasoline biodegradation in soil. Biodegradation 6: 127-140.

41. Ebere JU, Wokoma EC, Wokocha CC (2011) Enhanced remediation of a hydrocarbon polluted soil, Research journal of environment and earth science 3: 70-74. 